\title{
THE INSTITUTE OF NAVIGATION
}

THE овJвст of the Institute is to unito in one body those who are con1 cerned with or who are interested in the science and art of navigation. Membership is not restricted to those who hold professional qualifications, but is open to others who wish to further the aims of the Institute.

By coordinating the knowledge and achievements of marine and air navigators, scientists and those associated with the development and production of navigational equipment, the work of the Institute is directed towards raising the atandard of navigation. In the field of education it is the aim of the Institute to bring practical navigators into contact with teachers and research workers to increase a common appreciation of the issues involved. It is an object of the Institute to encourage research in equipment and methods; through its publications it gives a wide circulation to original work on navigation so that new developments and suggestions can be appreciated by those most directly concerned with them.

The activities of the Institute include the holding of monthly meetings to discuss specific problems, the publication of a Journal and of other works concerned with different aspects of navigation, and such other activities as the Council may deem necessary to promote knowledge in navigation and its anociated sciences.

The Journal of the Instituts of Narigation is issued free each quarter to all members and contains a full account of the Institute's proceedings. It prints the papers which are presented at meetings, together with their ensuing discussion, and other original papers contributing to the science of navigation. It also contains a record of current navigational work, reviews of important books, and general papers of interest to navigators and those with similar interests.

The work of the Institute is coordinated with that of similar societies abroad, and in particular with the work of the United States and Commonwealth Institutes of Navigation, whose proceedings are available to members.

Membership. There are five classes of membership of the Institute:

(1) HONORART MRMBRRs, who ahall be distinguished persons upon whom the Council may see fit to confer an honorary distinction.

(2) FBLLOW: who shall be members, of at least three years' standing who, in the opinion of the Council, have made a contribution of value to navigation.

(3) MzMBrzs, who shall be persons over twenty-one years of ago who can matisfy the Councll of their interest in navigation.

(4) STUDRNT MRMBrRs, who shall be persons under twenty-five years of age studying with a view to making navigation, or an allied intereat, their career.

(5) CORPORATB MRMBRRs, who shall be companies, universities, navigation schools, government departments and other orgenizations, here and abroad, who are directly or indirectly interested in the science of navigation. Corporate Members are entitlod to send representatives to all Institute meetings and to receive six coples of the Journal, and other publications. They are encouraged to take an active part in the Institute's work. Application should be by letter addressed to the Executive Secretary.

Subscriptions. Annual subscriptions to the Institute are payable in advance as follows:

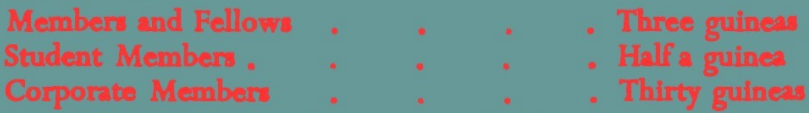

The Institute's financial year begins on I July. Members in any category who are elected after I January in any year are only due for one haif of their submaription until If July, when the full subscription for tho next year becomes duo, 